\title{
Microarchitecture and Radiological Flow Pattern of Cocoon-like Nanocellulose Hydrogels
}

\author{
Luismar Marques Porto ${ }^{a}$, Sílvia Machado Abreuc, Derce de Oliveira Souza Recouvreux ${ }^{a}$,
}

Fernanda Viera Berti ${ }^{a}$, Carlos Renato Rambo ${ }^{b *}$

${ }^{a}$ Laboratório de Tecnologias Integradas, Departamento de Engenharia Química e Alimento, Universidade Federal de Santa Catarina (UFSC), Florianópolis, SC, Brasil

${ }^{b}$ Departamento de Engenharia Elétrica e Eletrônica, Universidade Federal de Santa Catarina (UFSC), Florianópolis, SC, Brasil

'Instituto do Coração Socimed (SOCICOR), Tubarão, SC, Brasil

Received: May 2, 2018; Revised: October 9, 2018; Accepted: November 23, 2018

This work investigates fluid mechanics and structural properties inside bacterial cellulose hydrogels in from of macroscopic anisotropic ellipsoid body cocoon-like 3D scaffolds. The hydrogels were evaluated by injections of iopamidol, a radiopaque medium used in medical radiological procedures. Results showed that hydromechanical behavior of BC hydrogels may be used to characterize its internal structure. It is suggested that internal barriers and flow distribution anisotropy may be used to develop novel therapeutic applications based on the tissue engineered multifunctional possibilities of the biomaterial.

Keywords: Radiological analysis, Flow patterns, Bacterial nanocellulose, Tissue engineering, 3 D Hydrogels.

\section{Introduction}

The development of advanced bacterial nanocellulose (BNC) hydrogels should rely on their internal structure and fluid mechanics properties ${ }^{1-3}$. For drug delivering systems and tissue engineering constructs the ability to withhold a great amount of water is of no additional value if structural barriers cannot be used to sustain therapeutic effects, to segregate antagonist biochemical properties such as redox pairs, and to control degradation, tissue uptake and drug release rates ${ }^{4}$.

Pseudo-homogeneous and non-uniform, non-isotropic hydrogels have potentially important applications in novel tissue engineering 3D constructs ${ }^{2,5-12}$. Hydrogels are been discussed and postulated as strong candidates for the development of smart materials, mostly because they may mimic actual living systems, including cells, tissues and organs $^{13-21}$. Their capacity to hold water in a cross-linked structure is among the most frequently cited desired property ${ }^{4,22-24}$. Nevertheless, fluid mechanics of hydrogels are not fully exploited. Literature reports on BNC hydrogels are limited to membranes and small $\left(<1 \mathrm{~cm}^{3}\right)$ bodies. We have recently produced biosynthetic hydrogels based on networked and entangled fibers of bacterial cellulose. They may be grown until macroscopic bodies $\left(\geq 100 \mathrm{~cm}^{3}\right)$ that resembles silk cocoons ${ }^{13}$. The main difference between cocoon-like hydrogels and membranes is that the first are composed of a fibrous membrane with high fiber density that completely involves a less dense fibrous network, while membranes exhibit two distinct sides: an air-exposed upper surface, with high fiber density and a lower immersed surface that exhibits a higher porosity. Those cocoons can be created by Gluconacetobacter hansenii (formerly known as Acetobacter xylinum) in well defined hydrodynamic culture media. Macroscopic bodies that can vary from a few to more than one hundred cubic centimeters may have very complex internal structures that are challenging to characterize ${ }^{25}$. Usual characterization techniques assess static properties of biomaterials without considering the aqueous environment capacity to direct and retain exogenous biomolecules and other biological or mineral compounds and their mutual interactions. In this work we consider the hydromechanical characterization of bacterial cellulose hydrogels tailored to present particular 3D constructs suitable for several tissue engineering applications. The flexibility of contrast injection technique is used to follow fluid patterns and to analyze internal structure, permeability, construct resistance, elasticity and swallow properties based on radiological videos and images (see Table 1 for terminology adopted in this work).

Radiopaque contrast agents are used in computer tomography (CT) scans and other radiologic (X-ray) imaging to characterize blood vessel flows, organs, and other nonbony tissues ${ }^{26}$. We found that they may be also useful to characterize hydrogel constructs based on bacterial cellulose for applications in tissue and organ engineering.

Here, we report the use of a nonionic contrast agent (Iopamidol solution) to characterize qualitative the internal structure of nanofibrous hydrogels, by means of X-Ray imaging of the injected solution flow. 
Table 1. Glossary of hydrogel characteristics and hydromechanical flow-relatated definitions.

\begin{tabular}{|c|c|}
\hline Parameter & Definition \\
\hline BNC & Bacterial nanocellulose \\
\hline Cocoon & $\begin{array}{l}\text { A macroscopic hydrogel ellipsoid body } \\
\text { formed by interlaced and entangled bacterial } \\
\text { cellulose fibers, produced by particular } \\
\text { agitated and defined culture medium }\end{array}$ \\
\hline $\begin{array}{l}\text { Granular } \\
\text { cocoon }\end{array}$ & $\begin{array}{l}\text { A cocoon with internal discrete granules of } \\
\text { cellulose fibers inside the hydrogel }\end{array}$ \\
\hline Percolation & $\begin{array}{l}\text { The process of natural or forced (field- } \\
\text { driven) internal fluid diffusion, advection or } \\
\text { trickling }\end{array}$ \\
\hline Perfusion & $\begin{array}{l}\text { The process of forcing a fluid through } \\
\text { the hydrogel body skin to its external } \\
\text { environment (air, liquid, tissue or organ) }\end{array}$ \\
\hline Permeability & $\begin{array}{l}\text { Capacity of the hydrogel body to allow } \\
\text { gases or liquids to pass through due to pores } \\
\text { or openings in its internal structure }\end{array}$ \\
\hline $\begin{array}{l}\text { Pseudo- } \\
\text { homogeneous } \\
\text { cocoon }\end{array}$ & $\begin{array}{l}\text { A gelatinous dispersed fibrous phase of } \\
\text { bacterial cellulose }\end{array}$ \\
\hline $\begin{array}{l}\text { Skin } \\
\text { permeability }\end{array}$ & $\begin{array}{l}\text { Permeability of the exterior membrane of } \\
\text { BNC hydrogel cocoons }\end{array}$ \\
\hline
\end{tabular}

\section{Materials and Methods}

The strain of $G$. hansenii ATCC 23769 from the Collection of Tropical Culture (CCT, André Tosello Foundation, Campinas-SP, Brazil) was used to synthesize bacterial cellulose structures. The culture medium was prepared by dissolving $25.0 \mathrm{~g}$ mannitol, $5.0 \mathrm{~g}$ yeast extract and $3.0 \mathrm{~g}$ bactopeptone in 1 liter of water. $\mathrm{pH}$ was adjusted to 6.6 with $\mathrm{NaOH}$.

The macroscopic 3D hydrogels were produced according to the method previously described ${ }^{13}$. Briefly, an aliquot of $5 \%$ of a growing culture that had been stirred vigorously to release cells from the cellulosic mass was inoculated in $100 \mathrm{~mL}$ conical flasks containing $50 \mathrm{~mL}$ of sterile medium culture (sterilized at $121^{\circ} \mathrm{C}$ for $20 \mathrm{~min}$ ). Experiments were conducted on a rotary shaker (Nova Ética Mod 430/RDBP, Vargem Grande Paulista, SP, Brazil) operating at rotational frequency of $3.3 \mathrm{~Hz}$, for 14 days at $30^{\circ} \mathrm{C}$. All experiments were carried out in triplicate. Large $\left(\geq 100 \mathrm{~cm}^{3}\right)$ BNC hydrogel bodies were harvested from the rotary shaker flasks and treated with $0.1 \mathrm{M} \mathrm{NaOH}$ at $90^{\circ} \mathrm{C}$ for $20 \mathrm{~min}$ in order to remove impurities and cells that remained adhered to cellulose, and thoroughly washed in water until neutral $\mathrm{pH}$. Hydrogel cocoons were finally washed with distilled water. After synthesis, purification and washing, samples were conditioned in a $20 \%$ ethanol solution for storage at $4^{\circ} \mathrm{C}$. Before submitted to radiological analysis, hydrogel constructs were submitted again to autoclave treatment at $121^{\circ} \mathrm{C}$ for $20 \mathrm{~min}$.

Bacterial cellulose cocoons were injected with a $10 \mathrm{~mL}$ hypodermic, Luer Lok tip, clarified polypropylene barrel syringe (Becton Dickinson Indústria Cirúrgica Ltda, Curitiba-
PR, Brazil), filled with Iopamiron ${ }^{\circledR}$ 370, a nonionic contrast agent (iopamidol $755 \mathrm{mg} \cdot \mathrm{mL}-1$, Schering) delivered through stainless steel needles (Becton Dickinson, BD Medical Systems). Visualization was performed under a CIGNUS/ VMI Meditech S.A. Medical Technology angiographic system (Cardio Centro Diagnóstico, SociCor - Instituto do Coração SOCIMED, Tubarão-SC, Brazil). X-ray source was adjusted to $40 \mathrm{kV}$ and $400 \mathrm{~mA}$. Iopamidol, $\mathrm{C}_{17} \mathrm{H}_{22} \mathrm{I}_{3} \mathrm{~N}_{3} \mathrm{O}_{8}$, a nonionic, water-soluble contrast agent with molecular weight of $777 \mathrm{~g} \cdot \mathrm{mol}-1$, which is used in myelography, arthrography, nephroangiography, arteriography, and other radiological procedures (PubChem Project, National Center for Biotechnology Information, 2009) was withdrawn from a $50 \mathrm{~mL}$ vial and manually delivered under laminar flow conditions using a clinical syringe. Reynolds number was estimated at $256 \pm 26$ for cocoon analysis with some intermittent injections. Injections were carried out through a needle carefully positioned to show advection and contrast agent spreading. An angiography stainless steel needle of $0.64 \mathrm{~mm}$ of internal diameter and $40 \mathrm{~mm}$ length was used in BNC cocoons.

Previously developed cocoons were used for characterization and internal granular BNC cocoons hydrogels of $1 \mathrm{~g} \cdot \mathrm{cm}^{3}$ density were both injected with $1 \mathrm{~mL}$ of nonionic contrast for 8 seconds at $125 \mu \mathrm{L} \cdot \mathrm{s}-1$. A regular bevel (sharp angular tip at the end of the cannula) and regular wall thickness needle was used, thus allowing piercing the cocoon external skinny membrane with low penetration force and minimal drag, following manufacturer's guidelines.

The micromorphology and microstructure of the 3D hydrogels were evaluated by Scanning Electron Microscopy (SEM, Philips, XL-30). For the observations, samples with diameters of $5 \mathrm{~mm}$ were liofilized and placed over an aluminum support and sputtered with gold.

\section{Results and Discussion}

Figure 1 shows a photograph of a 3D hydrogel (cocoon) of approximately $60 \mathrm{~g}$ produced in a conical flask with $50 \mathrm{~mL}$ of culture medium. Excess and perfused fluid may be seen around the hydrogel body. density of $0.99 \mathrm{~g} \cdot \mathrm{cm}^{-3}(0.01$ Its water embedded saturated volume is approximately $120 \mathrm{~cm}^{3}$. The dimensions of the cocoons depend on the initial volume of the medium and flask geometry as reported previously ${ }^{13}$. $\mathrm{BNC}$ cocoons exhibit a gelatinous structure in their inner part, completely enclosed by a nanofibrous denser membrane. This membrane is formed under specific hydrodynamic conditions, where the cocoon-like body is continuously surrounded by a living bacterial layer, which forms a progressive shell membrane that covers the gelatinous inner part. In large bodies, this external membrane is a dense, interconnected, cellulose nanofiber network that resembles a skin.

In tissue engineering completely homogeneous and isotropic materials may not be as useful as structured scaffolds 
where cells are phenotypically differentiated according to their local microenvironment. The cocoons described here are hierarchically structured from their internal core up to their external membrane. The internal structure of the developed cocoons can be visualized against intense lightning, as shown in Figure 2.

Three regions can be identified: i) a transparent, uniform mass that surrounds the body, delimited by a skinny membrane; ii) an intermediary, diffuse network of entangled fibers and granules (Shown by arrows in Figure 2a) and iii) discrete, denser fiber agglomerates forming different geometries (Figures $2 \mathrm{~b}$ and $\mathrm{c}$ ). These fiber agglomerates form cellulose bundles with diameters ranging between hundreds of

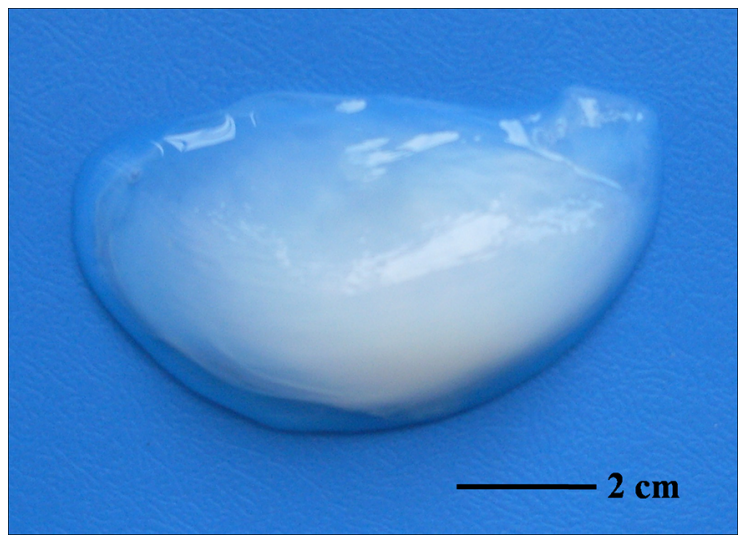

Figure 1. A pseudo-homogeneous bacterial cellulose cocoon laying on a flat surface just after removal from a $20 \%$ ethanol solution. micrometers and few millimeters, as displayed in details in Figure $2 \mathrm{~d}$. These micro and millimetric scaled features are responsible for the flow pattern of fluids inside the cocoons, acting as structured barriers that define the flow geometry and regime, and flux direction.

Figure 3 shows SEM micrographs of a liofilized cocoon. The voids observed in Figure 3a were probably formed as a result of fibril islands coalescence, resulting in free spaces between these islands. The external surface of the $3 \mathrm{D}$ cocoon exhibits a dense random assembly of interconnect ultrafine fibers network structure, composed of fibers with average diameter ranging from 50 to $100 \mathrm{~nm}$ and relative fiber density of 0.91 (Figure 3b). Examination of the fractured section (Figure 3c) revealed an internal micro architecture that consists of a hierarchically organized arrangement constructed of fibrous cell units, which form a honeycomblike morphology.

Iopamidol internal flow distribution and recirculation patterns in bacterial cellulose hydrogels were examined in ellipsoid (cocoon-like) samples as shown in Figure 4. Strong dependence on internal and external skinny membrane texture and fiber density was observed.

Recirculating flow was noticed when the contrast agent was tangentially injected in the pseudo-homogeneous cocoon however, surprisingly, with spiral patterns formed in the plane perpendicular to the tangential injection path. Figure 4a shows needle positioning and radiological flow image after 4 seconds of injection. This is most likely due

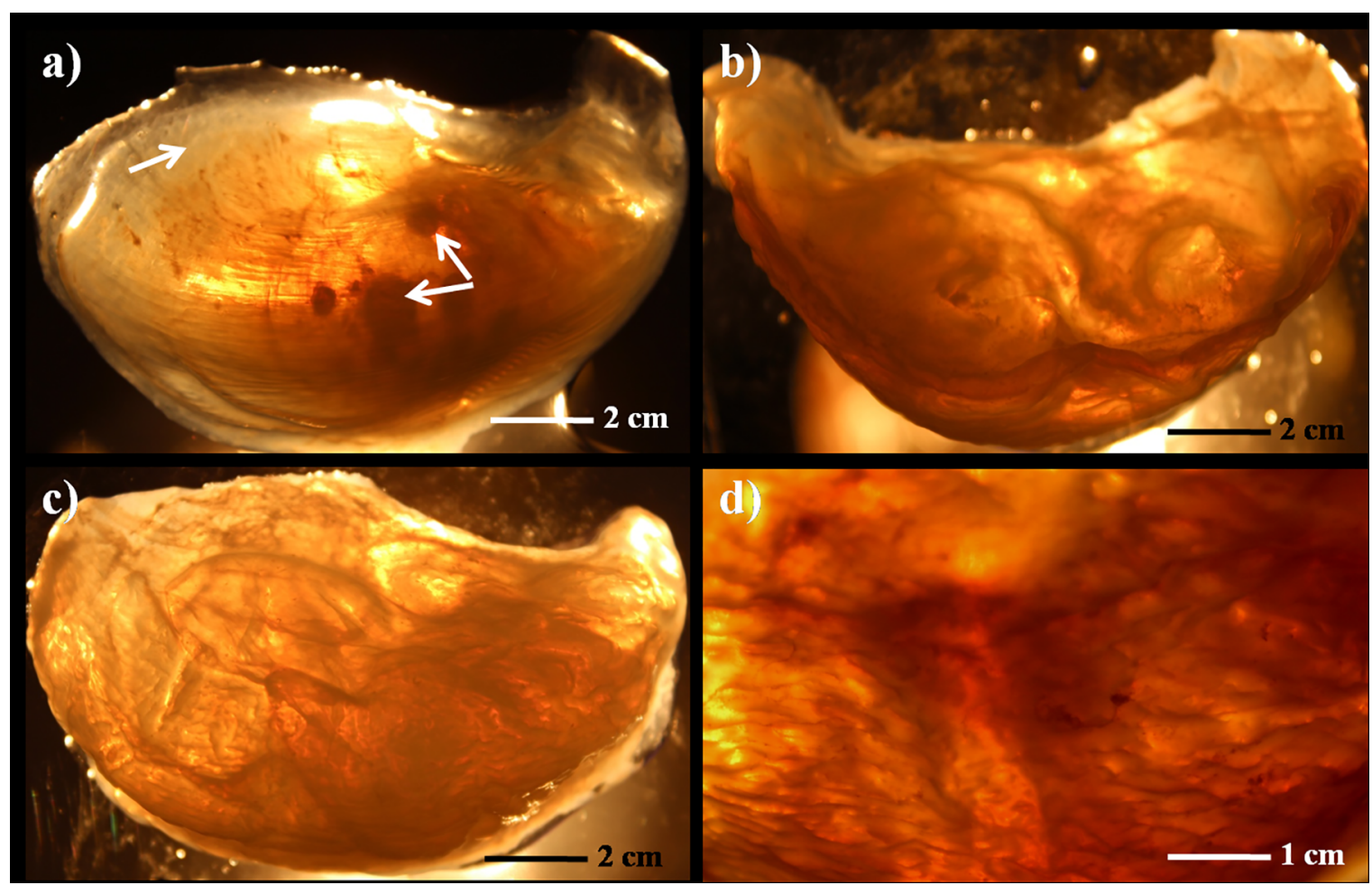

Figure 2. Optical images of a bacterial cellulose cocoon showing the internal structure of cellulose fibers inside the hydrogel: a) Granular cocoon; b)-d) Pseudo-homogeneous cocoon. 

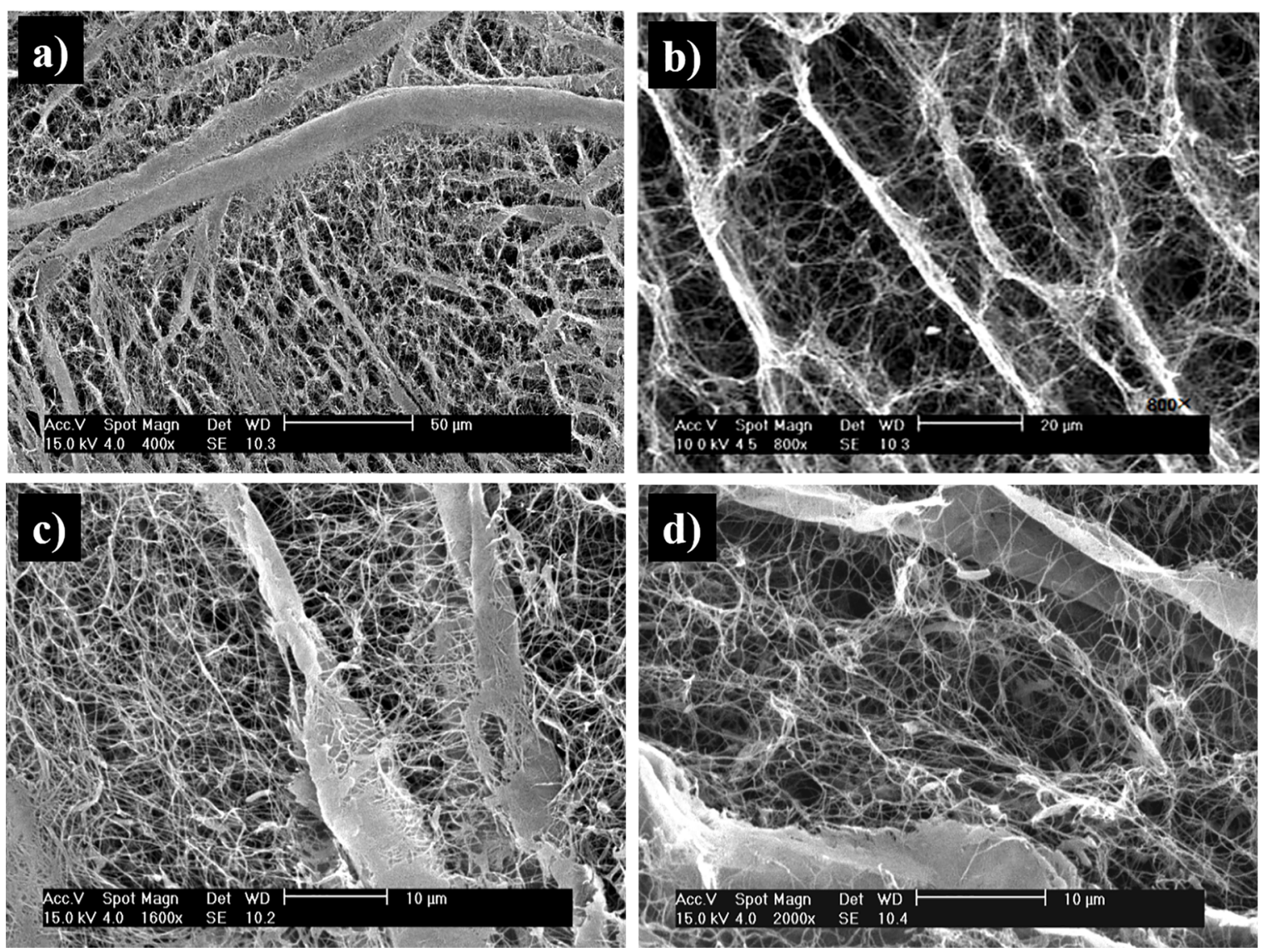

Figure 3. Scanning electron microscopic (SEM) image showing several layers of internal membranes, naturally developed during BNC synthesis under agitated culture.

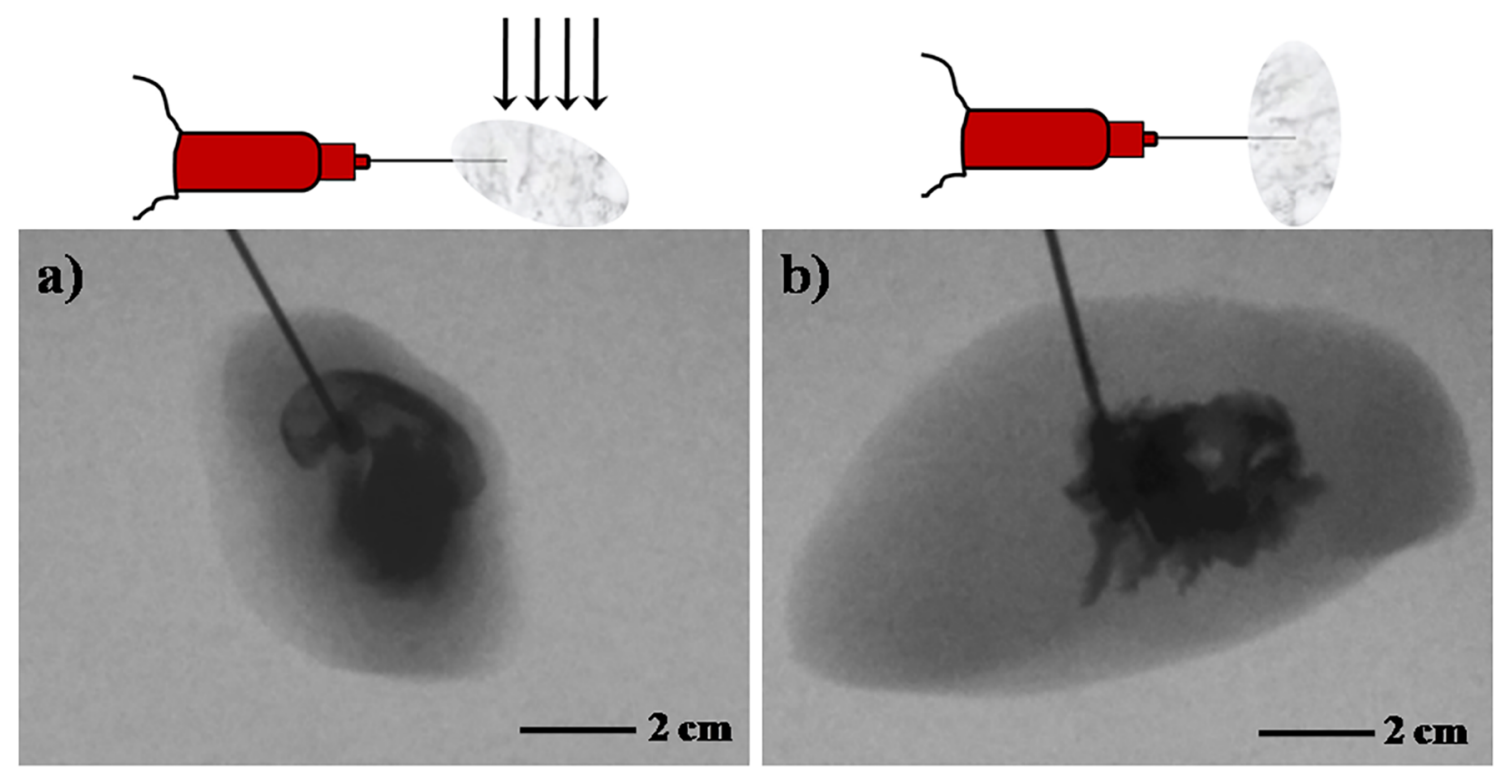

Figure 4. Contrast agent (iopamidol solution) injection scheme and radiological top view images of bacterial cellulose hydrogels under laminar injection flow: a) Pseudo-homogeneous BNC cocoon and the developed spiral-like fluid recirculation; b) Granular BNC cocoon and the percolation ramification pattern, around internal fiber granules. Down arrows represent incident X-ray bean direction. 
to the preferential channels formed around fibril aggregates and pseudo-membrane structures internally formed during the bacterial cellulose synthesis ${ }^{13}$. When contrast agent is injected in the more granular cocoon (Figure $4 \mathrm{~b}$ ), a cabbage flower type of pattern emerges, revealing internal aggregates, vacuoles and dense fibril islands. Besides the external skinny membrane that is typical of those cocoons and other BNC bodies, a subcutaneous dense external involucrum is also seen by visual inspection and revealed by the contrast. It is easily seen that this external layer concentrates most of the BNC mass of macroscopic hydrogel bodies.

The outer membrane exhibits enough resistance to hold the geometrical rearrangement, also allowed by the natural elasticity of the external membrane (skin). Only under relatively high pressure and very saturated conditions, we have observed contrast (iopamidol) solution perfusion. Further studies are needed to evaluate diffusion, permeation, percolation and perfusion of macromolecular compounds, in particular of transcription factors, hormones, large proteins, and nucleic acids in the macroscopic bodies of BNC hydrogels. Threedimensional macroscopic bodies synthesized by static and agitated cultures of $G$. hansenni under appropriate conditions allow for a variety of applications in the biomedical field, particularly in drug delivery/reaction systems and tissue engineering implants.

\section{Conclusions}

We have demonstrated that iopamidol, a nonionic contrast agent, can be used to characterize bacterial cellulose hydrogel macroscopic bodies. Those $3 \mathrm{D}$ constructs are potential candidates for smart tissue engineering scaffolds, particular due to their compartmentalization, that can be somewhat controlled by adjusting hydrodymechanical forces and culture media parameters. The quick spread of iopamidol, a $777 \mathrm{~g} \cdot \mathrm{mol}-1$ molecule, inside bacterial cellulose hydrogel constructs indicates that similarly large molecular weight hydrophilic agents may be able to easily diffuse (permeate) in their internal gel structure. On the other hand, the surrounding dense fibrous membrane of BNC cocoons do not allow easy path to their exterior (perfusion). Further studies are needed to evaluate diffusion, permeation, percolation and perfusion of macromolecular compounds in the macroscopic BNC hydrogels reported here. It is suggested, though, that they constitute a valuable platforms for drug tests, tissue development and multifunctional scaffolds.

\section{Acknowledgements}

We would like to thank the financial support of $\mathrm{CNPq}$ and FINEP (Ministry of Science and Technology of Brazil). L.M. Porto wishes also to thank Mr. Julio Cesar Preve for his help and support in the CAT scan lab.

\section{References}

1. Bryant SJ, Cuy JL, Hauch KD, Ratner BD. Photo-patterning of porous hydrogels for tissue engineering. Biomaterials. 2007;28(19):29782986.

2. Drury JL, Mooney DJ. Hydrogels for tissue engineering: scaffold design variables and applications. Biomaterials. 2003;24(24):43374351 .

3. Peppas NA, Bures P, Leobandung W, Ichikawa H. Hydrogels in pharmaceutical formulations. European Journal of Pharmaceutics and Biopharmaceutics. 2000;50(1):27-46.

4. Wu YB, Joseph S, Aluru NR. Effect of Cross-Linking on the Diffusion of Water, Ions, and Small Molecules in Hydrogels. Journal of Physical Chemistry B. 2009;113(11):3512-3520.

5. Tyliszczak B, Pielichowski KJ. Novel hydrogels containing nanosilver for biomedical applications - synthesis and characterization. Journal of Polymer Research. 2013;20:191-195.

6. Kim J, Yaszemski MJ,Lu L. Three-Dimensional Porous Biodegradable polymeric Scaffolds Fabricated with Biodegradable Hydrogel Porogens. Tissue Engineering Part C: Methods. 2009;15(4):583594.

7. Gillette BM, Jensen JA, Tang BX, Yang GJ, Bazargan-Lari A, Zhong $\mathrm{M}$, et al. In situ collagen assembly for integrating microfabricated three-dimensional cell-seeded matrices. Nature Materials. 2008;7(8):636-640.

8. Abd El-Mohdy HL. Radiation synthesis of nanosilver/poly vinyl alcohol/cellulose acetate/gelatin hydrogels for wound dressing. Journal of Polymer Research. 2013;20:177-188.

9. Backdahl H, Esguerra M, Delbro D, Risberg B, Gatenholm P. Engineering microporosity in bacterial cellulose scaffolds. Journal of Tissue Engineering and Regenerative Medicine. 2008;2(6):320230.

10. Fedorovich NE, Alblas J, de Wijn JR, Hennink WE, Verbout AJ, Dhert WJA. Hydrogels as extracellular matrices for skeletal tissue engineering: state-of-the-art and novel application in organ printing. Tissue Engineering. 2007;13(8):1905-1925.

11. Million LE, Guhados G, Wan W. Anisotropic polyvinyl alcoholbacterial cellulose nanocomposite for biomedical applications. Journal of Biomedical Materials Research Part B Applied Biomaterials. 2008;86B(2):444-452.

12. Moraes PRFS, Saska S, Barud H, Lima LR, Martins VCA, Plepis AMG, et al. Bacterial Cellulose/Collagen Hydrogel for Wound Healing. Materials Research. 2016;19(1):106-116.

13. Recouvreux DOS, Rambo CR, Berti FV, Carminatti CA, Antônio RV, Porto LM. Novel three-dimensional cocoon-like hydrogels for soft tissue regeneration. Materials Science and Engineering: C. 2011;31(2):151-157.

14. Jia XQ, Kiick KL. Hybrid Multicomponent Hydrogels for Tissue Engineering. Macromolecular Bioscience. 2009;9(2):140-156.

15. Thébaud NB, Pierron D, Bareille R, Le Visage C, Letourneur D, Bordenave L. Human endothelial progenitor cell attachment to polysaccharide-based hydrogels: A pre-requisite for vascular tissue engineering. Journal of Materials Science: Materials in Medicine. 2007;18(2):339-345. 
16. Rivest C, Morrison DWG, Ni B, Rubin J, Yadav V, Mahdavi A, et al. Microscale hydrogels for medicine and biology: synthesis, characteristics and applications. Journal of Mechanics of Materials and Structures. 2007;2(6):1103-1119.

17. Kopecek J, Yang J. Hydrogels as smart biomaterials. Polymer International. 2007;56(9):1078-1098.

18. Khademhosseini A, Langer R. Microengineered hydrogels for tissue engineering. Biomaterials. 2007;28(34):5087-5092.

19. Barcili B. Hydrogels for tissue engineering and delivery of tissue-inducing substances. Journal of Pharmaceutical Sciences. 2007;96(9):2197-2223.

20. Stumpf TR, Pértile RAN, Rambo CR, Porto LM. Enriched glucose and dextrin mannitol-based media modulates fibroblast behavior on bacterial cellulose membranes. Materials Science and Engineering: C. 2013;33(8):4739-4745.

21. Berti FV, Rambo CR, Dias PF, Porto LM. Nanofiber density determines endothelial cell behavior on hydrogel matrix. Materials Science and Engineering: C. 2013;33(8):4684-4691.
22. Kuckling D. Responsive hydrogel layers-from synthesis to applications. Colloid and Polymer Science. 2009;287(8):881891.

23. Karimi A. Investigation the effect of cross linking agent on equilibrium swelling and kinetics of water absorption and desorption for $\mathrm{pH}$ and $\mathrm{pH}$-temperature sensitive hydrogels. Asian Journal of Chemistry. 2008;20(5):3482-3488.

24. Lee JM, Pawlak JJ, Heitmann JA. Longitudinal and concurrent dimensional changes of cellulose aggregate fibrils during sorption stages. Materials Characterization. 2010;61(5):507-517.

25. Yang Y, Bagnaninchi PO, Ahearne M, Wang RK, Liu KK. A novel optical coherence tomography-based micro-indentation technique for mechanical characterization of hydrogels. Journal of The Royal Society Interface. 2007;4(17):1169-1173.

26. Aime S, Calabi L, Biondi L, De Miranda M, Ghelli S, Paleari L, et al. Iopamidol: Exploring the potential use of a wellestablished x-ray contrast agent for MRI. Magnetic Resonance in Medicine. 2005;53(4):830-834. 